\title{
ABOUT EXISTENCE: \\ LEWIS R. GORDON ON HUMAN'S SUBJECTIVITY, INTER-SUBJECTIVE AFFILIATION AND THE RELATIONALITY OF KNOWLEDGE
}

\author{
A PROPÓSITO DA EXISTÊNCIA: \\ LEWIS GORDON SOBRE A SUBJETIVIDADE HUMANA, AFILIAÇÃO \\ INTERSUBJETIVA E A RELACIONALIDADE DO CONHECIMENTO
}

DOI: $\underline{\text { https://doi.org/10.20873/uft.2179-3948.2018v9n1p18 }}$

Li Beilei ${ }^{1}$

\begin{abstract}
In his investigations of the existence of being human and Africana existence, Lewis R. Gordon devotes much attention to human subjectivity, inter-subjective affiliation and the relationality of knowledge. The above three crucial issues involve such important philosophical and cultural problems as the relation among human beings' existence-in-the-world, cognition as subject, and their inter-subjective affiliation, revealing ties between human existence and the relationality of knowledge. Based on the Africana situation of existence, Gordon integrates Africana philosophy and his interpretation of Chinese philosophy in his reflection of the two crucial issues. He has listed such Chinese thinkers Lu Xun, Wang Yangming, Xiong Shili, Wang Ji, etc. as existentialists in the world. His philosophy of existence embodies an interracial and cross-cultural vision, inspiring us to further understand the connection and resonance of Africana philosophy and Chinese philosophy in illuminating the existence of humanity, including the spirit of cultural criticism that "seek[s] truth and critical thought," the dialectical methodology of cognition, and the stress on individuals' relations with other individuals and the world in which they live. Focusing on Gordon's thought on human subjectivity, inter-subjective affiliation and the relationality of knowledge, this article presents an exploration of the connotations of Gordon's Africana philosophy of existence and its significances for human understanding.
\end{abstract}

Keywords: existence; Lewis R. Gordon; subjectivity; inter-subjective affiliation; the relationality of knowledge.

Resumo: Em suas investigações sobre a existência do ser humano e da existência africana, Lewis R. Gordon dedica muita atenção à subjetividade humana, à afiliação intersubjetiva e à relacionalidade do conhecimento. As três questões cruciais acima envolvem problemas filosóficos e culturais tão importantes quanto a relação entre a existência-no-mundo dos seres humanos, a cognição como sujeito e sua afiliação intersubjetiva, revelando os laços entre a existência humana e a relacionalidade do conhecimento. Com base na situação africana de existência, Gordon integra a filosofia Africana e sua interpretação da filosofia chinesa em sua reflexão sobre as duas questões cruciais. Ele listou os pensadores chineses Lu Xun, Wang Yangming, Shion Xiong, Wang Ji, etc. como existencialistas no mundo. Sua filosofia de existência incorpora uma visão inter-racial e transcultural, inspirando-nos a entender melhor a

\footnotetext{
$1 \mathrm{Li}$ Beilei is a lecturer at Zhejiang Normal University, China. She has researched on African \& Africana literature and culture, Africana philosophy. Email: libeilei666@hotmail.com
} 
conexão e a ressonância da filosofia Africana e da filosofia chinesa na iluminação da existência da humanidade, incluindo o espírito da crítica cultural que "busca verdade e crítica". pensamento", a metodologia dialética da cognição e a ênfase nas relações dos indivíduos com outros indivíduos e com o mundo em que vivem. Concentrando-se no pensamento de Gordon sobre a subjetividade humana, a afiliação intersubjetiva e a relacionalidade do conhecimento, este artigo apresenta uma exploração das conotações da filosofia de existência Africana de Gordon e seus significados para a compreensão humana.

Palavras-chave: existência; Lewis R. Gordon; subjetividade; afiliação intersubjetiva; a relacionalidade do conhecimento.

\section{Introduction}

Lewis R. Gordon has expounded on the existence of being human and Africana existence in many of his works. In his systematic and detailed analyses of the crucial questions concerning this field, he has been rather concerned about humans' subjectivity as existents and the subjects of cognition, his inter-subjective relations and the relationality of knowledge. He has discussed the above three vital issues in his books, Fanon and the Crisis of European Man: An Essay on Philosophy and the Human Sciences (1995), Her Majesty's Other Children: Sketches of Racism from a Neocolonial World (1997), Bad Faith and Antiblack Racism (1999), Existentia Africana (2000), An Introduction to Africana Philosophy (2008), What Fanon Said: A Philosophical Introduction to His Life and Thought (2015); and essays "Racism as a Form of Bad Faith" (1993), "Antirace Rhetoric and Other Misrepresentations of Racism in the Present Age" (1995), "Existential Borders of Anonymity and Superfluous Invisibility" (2000). Human subjectivity, inter-subjective affiliation and the relationality of knowledge are closely interwoven with human existence in Gordon's philosophical and socio-cultural thought. In his profound reflections on the above four themes and their interrelated ties, certain resonances and spiritual dialogues that cross time and space may be found in Africana philosophy and Chinese philosophy, especially in the philosophical thought of $\mathrm{Lu} \mathrm{Xun}{ }^{2}$, Wang Yangming ${ }^{3}$, Xiong Shili ${ }^{4}$, Wang $\mathrm{Ji}^{5}$. With a comparative

\footnotetext{
2 Lu Xun (1881-1936), the great Chinese writer, philosopher, translator and revolutionist, was born in Shaoxing, Zhejiang Province, China. His main works are a collection of fiction, The True Story of Ah Q, Pang Huang (Wandering About), an anthology of essays Dawn Flowers Picked up in the Dark, an anthology of prose poems Weeds, and collections of miscellaneous works Tomb, Hot Wind, etc. His works and thought have exerted great influence on Chinese literature and the history of Chinese thought.

3 Wang Yangming (1472-1528) was born in Yuyao, Zhejiang Province, China. He was one of the most influential philosophers and thinkers in the Ming Dynasty. His philosophy of mind, and theory of realizing and
} 
interpretation of Gordon's and the above Chinese philosophers' elaborations on human existence, subjectivity, inter-subjective affiliation and the relationality of knowledge, this article aims to further elaborate the cosmopolitan vision and significance of Gordon's Africana philosophy of existence, and delve into the dialogic possibilities between Africana philosophy and Chinese philosophy on the subject of human existence.

\section{Human subjectivity in existence and cognition}

Gordon's exploration of the human's existence as a subject and his inter-subjective affiliation, is always embodied in his reading and anatomization of such Africana writers and thinkers as Anton Wilhelm Amo, Franz Fanon, W.E.B. Du Bois, Richard Wright, Ralph Ellison, Toni Morrison, and others. His exploration focuses on two dimensions: one is the subjectivity and agency of humans as the subjects of existence and cognition; the other is the relationship between an individual's existence as a subject and his/her inter-subjective affiliation.

The subjectivity of the black individual in cognition has long been ignored by Western traditions of knowledge, therefore many closed and static concepts and categories were constructed and formed. Gordon has exposited that racial prejudice and colonialism have an “oppressive force of interpellation” (2008, p. 146) on the black's humanity and intellect. Gordon's Africana philosophy of existence interrogates Western epistemological conventions and maintains that the subjectivity of the subject in cognition is no less important than cognitive activity and knowledge.

In addition to his/her inner life and thought, the black's status of subject and agency in existence and cognition has often been doubted, depreciated or ignored. Gordon has examined and interpreted the concept of the human, and how Franz Fanon, Phyllis Wheatley, Anna Julia Cooper, W.E.B. Du Bois, James W. Johnson, Richard Wright, James Baldwin, Ralph Ellison,

practicing conscientious and intuitive knowledge - the theory that everything in the world is a part of the organic whole - have made vital contributions to Chinese philosophy and human thought.

4 Xiong Shili (1885-1968) was an influential Chinese philosopher and among the pioneers of new Confucianism. He was born in Huanggang, Hubei Province, China. His main works include The New Doctrine of Consciousness as the First Cause and The Original Confucianism. Xiong's philosophical thought is significant to reflections on the essence of traditional Chinese culture.

5 Wang Ji (1498-1583) was an outstanding Chinese thinker in the Ming Dynasty, and one of the most important and accomplished students of Wang Yangming. With his Complete Works of Longxi, he further explored and advanced a few questions in Wang's thought on knowledge and conscience, and his philosophy of mind. 
Monifa Love, Zora N. Hurston, Alain Locke, Aime Cesaire, Angela Y. Davis, bell hooks and other Africana writers have represented the Black's humanity, agency and repressed subjectivity, along with reflections of his/her existential situation and unremitting quest for the meanings of existence. Fanon's observations are classic examples that show the repressed subjectivity of the black as an existent. The second chapter of Gordon's What Fanon Said centers on Fanon's fight against the paradox of Western reason and history. Fanon noticed that the black's being was anonymized and his/her situation of being was closed in the "zone of non-being". Thus Gordon clarifies that, "each black is ironically nameless by virtue of being named 'black.'... so blacks find themselves not structurally regarded as human beings. They are problematic beings, locked in what he (Fanon) calls "a zone of nonbeing" (2015, p. 22).

The "zone of nonbeing" may be understood as a state of uncertainty or total absence. Gordon further elaborates in An Introduction to Africana Philosophy that when "the black" collapses into "the blacks", and when "the black" collapses into "the black body" without a soul or inner world, the consciousness and structure of black's self are indifferently deleted. Gordon critiques the epistemic structures that label a black individual as the blacks; it takes the definition, portrayal and evaluation of the Africana people as a whole to replace the concern for each Africana individual. He reputes that, "the refusal to look into the perspective of the black is an act of treating the black as pure exteriority, a being without an inner life" (GORDON, 2012, pp. 10-11), and convincingly points out in his reading of Richard Wright's novel Native Son (1940) that

\begin{abstract}
A powerful feature of Wright's work is that Bigger Thomas is not only a mythopoetic trope in a fictional narrative. Wright chose the medium of the novel to explore the inner life of Bigger Thomas. The novel, in other words, shows how someone becomes Bigger Thomas, and even more unusual, Wright achieves this without compromising Bigger's agency. The choices Bigger makes are not the only ones he could have made, but they are the ones that make sense given the circumstances under which he lived" (GORDON, 2012, p. 10-11).
\end{abstract}

Since the black's existence has been defined and described as pure exteriority, his/her inner tensions, sufferings and anxiety have often been neglected, and thus the black has sometimes been forced to repress and sacrifice his/her authentic subject and self in the actual realm of socio-cultural life. According to Gordon, "each human being is expected to seek out his or her unique 'calling' in life, a view which places much agency or responsibility on individuals linked to a broad community of elders, ancestors, deities, and an ultimate being" (2008, p. 132) In Gordon's textual analysis, he holds that there is an existential situation of 
"confronting death for life's sake" in the stories of Bigger Thomas and Cross Damon. The life described here is a free and dignified life. The two protagonists, Bigger Thomas and Cross Damon, represent two manifestations of an Africana individual's life, and also are symbolic of the Africana subject's existential situation. Gordon deems that the black's reflections on existential situations and his/her unremitting quest for the meanings of existence have a long history and possess great profundity:

That conflicts over responsibility and anxiety, over life affirmation and suicidal nihilism, preceded Kierkegaardian formulations of fear and trembling raised questions beyond Eurocentric attachment to a narrow body of literature...

To find anxiety and dread, one needed to look beyond white America, and since North America wasn't populated solely by white people, finding these sources of concern wasn't difficult. As Anna Julia Cooper's A Voice from the South, W. E. B. Du Bois's Souls of Black Folk, Ralph Ellison's Going into the Territory, Frantz Fanon's Black Skin, White Masks, and Toni Morrison's Playing in the Dark have shown us, anxiety, dread, and despair were on the modern world's underside, in the blackness that it often sought to hide in its theoretical and aesthetic moments of self-representation (GORDON, 2000, p. 6-8).

Gordon condemns the psychological and spiritual traumas that racial prejudice and colonialism have brought to the black, and has determined that a constant inward deprecation of self ultimately begins with the idea of the self as an unjustified, problematic being (GORDON \& ALCOFF, 2003, p.180). Africana philosophy of existence respects each human individual and his/her lived reality. Each individual has his/her personality and individuality, and these cannot be substituted by another individual. The black's experience in life needs to be included, respected and understood within the framework of social knowledge. Gordon not only discusses the black's existential situation and his/her reflection on it in Africana works, but he also unveils the black's consciousness, inner life and spiritual world. As Sonia Dayan-Herzbrun writes in her preface to What Fanon Said:

Gordon reminds us that the hegemonic view is that theory is supposed to be left to white theorists (I shall add: better if they are male). Blacks are supposed to offer only their "experience," or to be followers and imitators, in other words to put a white mask on their black faces. But the experience of a black man or woman is literally not taken as a human experience, able to be universalized, because in the racial and colonial point of view, black people are not structurally regarded as human beings (DAYAN-HERZBRUN, 2015, p. xi-xii).

Dayan-Herzbrun's words indicate that since the black's subjectivity as human has long been ignored or denied, he/she has been required to provide experience instead of 
intellect, and his/her experience has been taken as lacking in universality. Both What Fanon Said and Gordon's many other works reveal a positive intention, which is to discover and investigate great Africana thinkers' and scholars' thoughts; to show their spiritual and intellectual world as well as the their agency as existents and subjects who cognize.

Similar to Fanon and Gordon, the Chinese thinker Lu Xun investigates the human's situation of nonbeing with scientific objectivity. Lu stresses the individuals' life. The characters Kong Yiji, Ah Q, and Xiang Lin are among the human individuals he depicted and reflected on. In the socio-cultural milieu of Lu's time, the individual suffered a great deal of set-backs and pains under a repressive social system. Wang Yangming, Xiong Shili and Wang Ji are among the Chinese philosophers who attached importance to human agency in existence and cognition, and the diversity of human individuality. The philosophical thought of Gordon and the above-mentioned Chinese philosophers embody a refusal to accept a pure reasoning from one category to another. They combine their reflection on phenomena with reflection on humans and humanity; the subject of cognition with the objects of cognition by interpreting and investigating the ways and meanings of humans' existence in the world.

\section{Human existence in inter-subjective affiliation}

Gordon critiques the Eurocentric traditions of philosophy and epistemology, as they ignore, weaken or even negate the subjectivity and inter-subjectivity of the black human in his existence and cognition. Africana philosophy of existence, which has discovered and discussed problems and reality in contradictions and conflicts, is seriously concerned with the human's inter-subjective affiliation in his existence. Take the "black problem" for instance. Is it the black's problem, the white's problem, or the problem of making the black a problem, or the problem that puts the black in the situation of confronting various black problems? This so-called problem should be identified and surveyed in human inter-subjective relations. Africana philosophy of existence insists that inter-subjective affiliation and human subjectivity are equally important in the individual's existence, and the significance of the inter-subjective affiliation among different individuals could and should not be weakened, neglected or denied. Gordon holds that a crucial feature of Africana philosophy of existence is its emphasis on the truth that human existence is the existence that impacts inter-subjectivity. He analyzes in "Bigger-Cross Damon: Wright's Existential Challenge" (2012) the symbolic 
connotations of the character Cross Damon as a "monster". He finds that a "monster" is actually the symptom of an abnormal society, and Africana philosophy of existence criticizes epistemology as a transcendent category or the first philosophy.

Africana philosophy of existence addresses the relationship between the self and others in a different way from such European existentialist as Sartre and Beauvoir. The former contemplates the relation between the self and others from the perspectives of existential philosophy, phenomenology and ethics. In analyzing the estrangement and alienation among people who live under colonialism or in a racially biased society, Gordon notes that, "the inferior Other becomes a fundamental project for the establishment of the Superior self, whose superiority is a function of what it is" (1997, p. 70). Gordon stresses that inter-subjective affiliation is in relation to the generation and performance of humans' ethical and moral responsibilities. The Chinese philosopher Wang Yangming also deems that humans' inter-subjective affiliation is closely linked to their morality. He explains that individuals as social existents form a coexistent relation in the same social space. Wang's emphasis on humans' emotional understanding similarly shows that the cultivation and practice of morality need to be conducted in inter-subjective affiliation (YANG, 2010, pp. 64, 73). ${ }^{6}$

The "monsters and queer things" that many Africana literary works reveal is a response to the multifarious queer theories that work in socio-cultural life. Africana philosophy of existence and the afore-mentioned literary works compel people to consider why the so-called "monsters and queer things" appear and whether they are truly queer. Gordon mentions in What Fanon Said that Fanon once treated psychotics by establishing the inter-subjective contact and communication among them by creating "the therapeutic community" (2015, p. 79). He believes that Fanon considered humans the entity of relations (Ibid. p. 127), and expressed a vital philosophical anthropological idea, that is, the human being is a relational reality, which means that genuinely human activity always reaches beyond itself (Ibid. p. 127). In What Fanon Said, Gordon also examines the far-reaching significance of Fanon's thought to humans' struggles against the situation of being oppressed and degraded. Fanon presents readers with the two issues that define existence: human subjectivity and inter-subjectivity, both of which stimulate innovative thinking. To respect and rethink human inter-subjective affiliation offers us an opportunity to rediscover the human self, his/her ties to others and the world he/she lives in. Embedded in Gordon's discussion of inter-subjective affiliation, is an

\footnotetext{
6 The quotes from Chinese works are mainly translated by this author.
} 
emphasis on the humanistic concern of human understanding and cultural diversity. He asserts that, "We are all part of one global community......we must all try to understand the many cultures and groupings that are part of all societies in order to develop a more thorough understanding of each other"

Such Chinese philosophers as Wang Yangming, Xiong Shili and Lu Xun underscore the affiliation and interaction among subjects. They see humans' sympathy, understanding, and communication with each other as noble. Wang believes that a myriad of experiences share one body; the others to me are by no means hell, but are co-existents who are in connection with me. ${ }^{8}$ Xiong Shili contends, "Each individual and everything are not a heap of sporadic and irrelevant loose sands, but a harmonious unity" (LI, 2007, p. 25). Xiong's philosophy highlights that every man's life is dynamically integrated with the life of the world (including other individuals, birds and beasts, plants and flowers, tiles and stones, etc.) (GUO, 2013, p. 45). Lu Xun depicts the indifference, conflicts and chasms among people, bitterly accentuating that individuals are by no means dissociative atoms. The admission and affirmation of the common and universal humanity is always the basis for understanding inter-subjective affiliation. Both Gordon and these Chinese philosophers advocate that an individual's closed situation centers his/her self and that the hierarchies an individual builds between other individuals and him/her self should be broken. Couched in their exploration of the affiliation between an individual and other individuals, is a positive adjustment of the potential dialogic directions, from "I-he/she/it" to "I-you, we-you, I-my self". This adjustment bridges the distance between the human subject and other subjects. And more crucially, it pushes the situation of speaking from the removed "I-others" discussion into the dialogic communication between "I and you, we and you, I and my self." Gordon's and the above-mentioned Chinese philosophers' explorations of human inter-subjectivity in existence virtually point to human social responsibility, awareness and concern for the common situation of existence. Nowadays, traditional knowledge and beliefs cannot fully satisfy the demands of modern life or solve human contradictions; many values have become ambiguous and questionable. In this context, the quest for humans' subjective and inter-subjective existence is especially crucial.

\footnotetext{
7 "Nelson Mandela visiting Professor: a meeting of many worlds," The Rhodes University Community Newsletter (The Staff Edition), Nov. 2014, p. 12-13: 13.

${ }^{8}$ See CHEN, Lai. Between being and non-being: the spirit of Wang Yangming's philosophy, Beijing: Peking University Press, 2013, p. 248.
} 


\section{The relationality of knowledge and human existence}

By stressing the relationality of knowledge, Gordon argues that knowledge is about being in relations with the world and each other, which opens and enriches the potentialities and possibilities of human communication. The rise of the Existentialist movement in the West was a response to the estrangement of reason from existence, and a revolt against rationalism (CHEN, 2013, p. 13). Knowledge is intimately linked to humans' existence as well as their relations with other individuals and the world. The relationality of knowledge has a close bearing on knowledge's value for reality and truth, as well as the human's authentic self that gives the subject intentions, courage and power to exist.

Let's begin the discussion on the nexus between the relationality of knowledge and reality with the meanings of "blackness". Through an in-depth reading of Africana literature and philosophy, we may understand that, on one hand, "blackness" represents "connection." It represents concepts related to the Black: material, cultural, spiritual or emotional. On the other, it embodies the life and the existential realities of people of African descent. The term "blackness" has varied and intricate meanings. When applying and translating it, making an annotation based on the specific context is rather necessary. The Chinese translation of "blackness" is usually the word “黑人性”. The etymology of the second Chinese character “人” shows that the character outlines the image of a human bending over, letting his arms dangle as he industriously works in the field. The third Chinese character “性” originally refers to the implicit embodiment of physical, intellectual, emotional instincts and desires. This particular character stresses the natural patterns of human. It finds resonance in Africana writers' and thinkers' use of "blackness", as the latter may place value on the reality and naturalness in representing the black. "Blackness" conveys Africana artists' and thinkers' intentions and expectations of the word, viz a viz blackness as the black's reality and authenticity, and his/her broad spiritual and emotional world.

Although there have been many stereotyped images of Africana people, which were constructed and spread in racialized representation systems that over-simplify, dwarf and misrepresent their socio-cultural image, blacks' authentic humanity and experiences in life ought not to be shrouded and ignored. A plethora of Africana literary and philosophical works 
have addressed this issue by displaying the rich world of the black's life in experience, his/her authentic humanity and reflections of existence. Gordon criticizes the disembodiment of knowledge from reality and highlights humans' authenticity even in a racially biased social environment. Racism is a normative trait of a racialized society, and thus the reason of a system. "The dominated group is displaced out of the lived-reality of cultural life." Fanon calls this as "the zombification of culture" (GORDON, 2015, p. 87). "Fanon examines this zombification as rituals of cultural performance, which are unnatural conditions of culture life" (Ibid.).

\begin{abstract}
If there exist preconceived ideas and biases in my mind, I could not see and grasp the authentic life and innate characteristics of people and things...now that these preconceived ideas and biases form a barrier to my comprehending, the images of people and things in the world would be distorted and deformed in my mind and consciousness, losing their truth and authenticity. It's thus inevitable that although I gain a deep understanding of people and things, truth and falseness, right and wrong are confounded (QIAN, 1999, p. 56, 91).
\end{abstract}

Biased knowledge handicaps humans in their meditations on existential situations and in their searches for the meaning of existence; it also hinders them from facing reality. "Racial constructions are leeches on all manifestations of human ways of living: language, sex, labor (material and aesthetic), socializing (reciprocal recognition), consciousness, and the "Soul"' (GORDON, 2015, p. 24). The black, who is often simplified and objectified as the black body, is reduced to an "epidermal two-dimensional as in Euclidean geometry" (Ibid. pp. 48, 50), incapable of sustaining a 'bridge' between 'subjective life and the world"' (Ibid. p. 48). The black's humanity and intellect, which are part of the reality and his/her authenticity, are made invisible. The black always finds himself/herself "caught, enmeshed in a web of designations, none of which he wanted, but all of which imposed themselves, enwrapping him (/her) in what seemed to be a sealed fate by which he feel to the ground, ready for the role set for him to play" (Ibid. p. 137).

Lu Xun places emphasis on reality and human authenticity, and depicts in his works the absurdity, contradictions and tragedies of human existence (ZHOU, 2016, p. 123). Lu describes human existence not by his authentic state of being imprisoned in an iron house, for this would prevent him from realizing his authentic subjectivity. Once racialized knowledge is produced, constructed and legitimatized, the meanings it produces and spreads contain many fallacies and denials of reality, and constantly impacts people's understanding of the black and 
his/her experiences in life. Knowledge involving fallacies and misunderstandings has consistently spread in the human world of meanings, which leads to the production and transmission of more fallacious knowledge, which has developed from the previous fallacious knowledge, and a vicious circle of fallacious knowledge takes shape thusly. The imposed self contradicts the authentic self, and thus causes the black existent anguish and anxiety. Gordon hereupon appeals that this is "taking reality seriously without placing a false domain or circle around it" (2008, p. 141). He also points out that "Wo ho' is the Akan rendition of 'exist'. Without the 'ho', which means "there", in other words, 'some place', all meaning is lost" (Ibid. p. 39). "Ho" highlights the spatial position. Africana philosophy of existence concerns both the reality of the human's situation and his consciousness. Different from Descartes' spiritual, non-spatial and non-material existence of self, Gordon's concept of existence is closely related to reality and the human's authentic self.

It is because that human consciousness plays such an important role in the construction and dissemination of knowledge that knowledge's nexus with human reality should be recognized and valued. Knowledge cannot be equated with reality. The second chapter of Dao Dejing by $\mathrm{Lao} \mathrm{Zi}^{9}$ illuminates this point:

\begin{abstract}
When all under Heaven know beauty as beauty, there is ugliness. When all know good as good, there is the not good. Being and non-being generate one another. Difficult and easy complement one another. Long and short give form to one another. High and low depend on one another. Music and voice harmonize one another. Front and rear follow one another. These are constant. (WU, 2013, p. 7).
\end{abstract}

In Lao Zi's dialectics, beauty and ugliness, good and evil, easy and difficult are all relative concepts and produced in the conceptual space of comparison. Their representation and denotation of reality is limited. Being is constituted from many concepts and categories, some of which contain subjective misjudgments and misunderstandings, as knowledge needs to be continuously interrogated and revised. Lao Zi's Dao Dejing encourages us to break through our perceptual and intuitive cognition of tangible things, and probe beyond appearances and into the depth of physical forms. This cognitive dialectics finds resonance in Africana philosophy of existence. The latter inspires people to break through the stereotyped

\footnotetext{
9 Lao Zi, also known as Li Er, was an eminent philosopher and thinker in the Spring and Autumn Period (770 B. C-476B. C) of Chinese history. He was the founder of Taosim whose work The Classic of the Virtue of the Tao (or Daode Jing) exerted great influence on Chinese philosophy, ethics and literature.
} 
images and concepts of Africana people and blackness. It calls on Africana people to break through the definitions and norms that racialized cultural representation imposes on them, and to understand their black selves in good faith.

Positive human cognitive activity is conducted in movement; its innate demand for progress makes it averse to stagnation. Human knowledge is in essence dynamic. It needs ceaseless revision and renewal. In their production of knowledge, humans should never stop seeking reality or authenticity, or stop overcoming the negativity their subjective consciousness and emotions bring to their construction of knowledge. Knowledge's separation and estrangement from human reality has negatively influenced humans' capacity for imagining and realizing possibilities. Africana philosophy of existence bases its foundation on social reality and human authenticity. Gordon asserts that

\begin{abstract}
African philosophers already have a reason to raise existential questions of liberation and questions of identity...by virtue of the historical fact of racial oppression manifested most vividly in the European and Arabic slave trades and the European colonization of the African continent and the entire world of color (GORDON, 1997, p. 3).
\end{abstract}

One of the main appeals of Africana philosophy of existence is to recognize and understand the situation or lived context of Africana people's being or existence in the world. Gordon has frequently analyzed bad faith in his works. Knowledge's estrangement from reality and authenticity is actually an embodiment of bad faith, which evades social reality and humans' authentic selves, while encircling human life in lies and falsehood. As the Chinese philosopher Xiong Shili explained, the nature of being and existence cannot be separated from phenomena. Philosophers' cognition and understanding of phenomena cannot substitute for cognition and understanding of the nature of being (JING, 2010, pp. 43, 128). We need to reexamine the production and legitimatization of knowledge that has negatively affected humans' socio-cultural life and inter-subjective relations, and "re-think the distortions we have created around the philosophy of what it is to be human"10. This contention by Gordon and the above-mentioned Chinese philosophers on the relationality of knowledge shows that, we ought to take the objective reality as the primary foundation, instead of severing this cognitive process from reality to form knowledge. Furthermore, it is indeed in

10 "Nelson Mandela visiting Professor: a meeting of many worlds," The Rhodes University Community Newsletter (The Staff Edition), Nov. 2014, p. 12-13: 12. 
bad faith to verify and affirm knowledge with assumptions of value and ideals. Although Africana philosophy and Chinese philosophy have grown out of different socio-cultural traditions, they both have within them the spirit of getting out of self-centered consciousness by seeking reality and authenticity. They further enlighten us to rethink the following question: how should we, as human beings, cognize and conceptualize human reality, human authenticity and past history?

\section{Epilogue}

In An Introduction to Africana Philosophy, Gordon writes that, "much of what we do as theorists of nature (scientists) or reality that includes nature (philosophers) is read phenomena." (2008, p. 45). His philosophy of existence values the reality of the human existential situation. Africana philosophy of existence is deeply rooted in the reality that the black subject has been heavily influenced by race and racial prejudice, as well as his/her life and cultural experiences. It has focused on both the experience of blacks and that of the black individual. Africana philosophy of existence also illuminates a lot of differences in theoretic origins, research questions and methods and viewpoints from European existentialism in the exploration of human existence and the relationality of knowledge. Gordon believes that to alter the geography of reason, we need to explore diverse philosophies of existence in the world. His reading of some Chinese philosophers is not merely because of his is partial Chinese ancestry and his interest in Chinese philosophy, but also due to his cross-racial and inter-cultural vision.

The discussion of human existence put forth by Gordon and the above-mentioned Chinese philosophers is grounded in these philosophers' emphasis on humans' subjectivity and inter-subjectivity as existents and the subjects of cognition, and their incisive observations and reflections on human anguish, despair and adversity. They wrote down and illustrated their ideas to promote greater understanding and discussions of such issues as human subjectivity and existence, knowledge and reality, self and others to aid in our comprehension of other individuals and the social world, and facilitate the creation of a more humane and benevolent world. These philosophers inspire people to actively negotiate the social world of meaning while interpreting and building upon existing knowledge. In the context of cultural globalization, Africana and Chinese philosophy will unfold more critical dialogues that 
explore human existence and knowledge, sparking new ideas and thought that will surely benefit all of humankind.

\section{References}

CHEN, Lai. Between being and non-being: the spirit of Wang Yangming's philosophy, Beijing: Peking University Press, 2013.

GORDON, Lewis R. An introduction to Africana philosophy. Cambridge: Cambridge University Press, 2008.

GORDON, Lewis R. What Fanon Said: a philosophical introduction to his life and thought. New York: Fordham University Press, 2015.

GORDON, Lewis R. Bigger-Cross Damon: Wright's existential challenge. In: Philosophical Meditations on Richard Wright, HAILE, James B., III. Lanham. MD: Lexington Books,

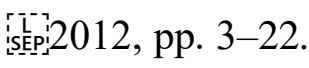

GORDON, Lewis R. Existentia Africana: understanding Afrciana existential thought. New York and London: Routledge, 2000.

GORDON, Lewis R., Linda Martín Alcoff. A philosophical account of Africana studies: an interview with Lewis Gordon. In: Nepantla: Views from South, 2003, pp. 165-189.

GORDON, Lewis R., Ed. Existence in black: an anthology of Black existential philosophy. New York: Routledge, 1997.

GUO, Qiyong. Xiong Shili. Beijing: China Social Sciences Press, 2013.

JING, Haifeng. The study of Xiong Shili's philosophical thought. Beijing: Peking University Press, 2010.

LI, Qingliang. A study of the hermeneutic thoughts of Xiong Shili, Chen Yinque and Qian Zhongshu. Beijing: Zhonghua Book Company, 2007.

QIAN, Zhongshu. Notes on literature and art. Beijing: Zhonghua Book Company, 1999.

$\mathrm{Wu}$, Charles Q. Thus spoke Laozi: Dao Dejing, a new translation with comments. Beijing: Foreign Language Teaching and Research Press, 2013.

YANG, Guorong. Wang Yangmin. Nanjing: Nanjing University Press, 2010.

ZHOU, Lingfei, Ed. The Study of Lu Xun's system of thought. Beijing: People's Daily Press, 2016. 